\title{
Light Intensity and Quality from Sole-source Light-emitting Diodes Impact Growth, Morphology, and Nutrient Content of Brassica Microgreens
}

\author{
Joshua R. Gerovac and Joshua K. Craver \\ Department of Horticulture and Landscape Architecture, Purdue University, \\ West Lafayette, IN 47907
}

Jennifer K. Boldt

USDA-ARS, Greenhouse Production Research Group, 2801 W. Bancroft Street, Mail Stop 604, Toledo, OH 43606

\author{
Roberto G. Lopez ${ }^{1}$ \\ Department of Horticulture, Michigan State University, 1066 Bogue Street, \\ Room A288, East Lansing, MI 48824
}

Additional index words. controlled environment agriculture, LEDs, multilayer production, urban agriculture

\begin{abstract}
Multilayer vertical production systems using sole-source (SS) lighting can be used for the production of microgreens; however, traditional SS lighting methods can consume large amounts of electrical energy. Light-emitting diodes (LEDs) offer many advantages over conventional light sources, including high photoelectric conversion efficiencies, narrowband spectral light quality (LQ), low thermal output, and adjustable light intensities (LIs). The objective of this study was to quantify the effects of SS LEDs of different light qualities and intensities on growth, morphology, and nutrient content of Brassica microgreens. Purple kohlrabi (Brassica oleracea L. var. gongylodes L.), mizuna (Brassica rapa L. var. japonica), and mustard [Brassica juncea (L.) Czern. 'Garnet Giant'] were grown in hydroponic tray systems placed on multilayer shelves in a walk-in growth chamber. A daily light integral (DLI) of 6,12 , or $18 \mathrm{~mol} \cdot \mathrm{m}^{-2} \cdot \mathrm{d}^{-1}$ was achieved from commercially available SS LED arrays with light ratios $(\%)$ of red:green:blue 74:18:8 $\left(R_{74}: G_{18}: B_{8}\right)$, red:blue 87:13 $\left(R_{87}: B_{13}\right)$, or red:far-red:blue 84:7:9 $\left(R_{84}: F_{7}: B_{9}\right)$ with a total photon flux (TPF) from 400 to $800 \mathrm{~nm}$ of 105,210 , or $315 \mu \mathrm{mol} \cdot \mathrm{m}^{-2} \cdot \mathrm{s}^{-1}$ for 16 hours. Regardless of LQ, as the LI increased from 105 to $315 \mu \mathrm{mol} \cdot \mathrm{m}^{-2} \cdot \mathrm{s}^{-1}$, hypocotyl length (HL) decreased and percent dry weight (DW) increased for kohlrabi, mizuna, and mustard microgreens. With increasing LI, leaf area (LA) of kohlrabi generally decreased and relative chlorophyll content (RCC) increased. In addition, nutrient content increased under low LIs regardless of LQ. The results from this study can help growers to select LIs and LQs from commercially available SS LEDs to achieve preferred growth characteristics of Brassica microgreens.
\end{abstract}

Microgreens and baby greens are a relatively new specialty crop appearing in many upscale markets and restaurants. Collectively, these crops consist of vegetables and herbs consumed at a young growth stage. The main difference between the two is that microgreens are harvested at the base of the

Received for publication 13 Nov. 2015. Accepted for publication $28 \mathrm{Feb} .2016$.

The USDA-NIFA SCRI grant no. 2010-51181-21369 for funding and Philips Lighting and Hort Americas for LED lighting.

We thank Maria Del Rosario Del Rio, Kristine Adamiec, and Sydney Moser for growth chamber and laboratory assistance.

The use of trade names in this publication does not imply endorsement by Purdue University, Michigan State University, or USDA-ARS of products named nor criticism of similar ones not mentioned.

${ }^{1}$ Corresponding author. E-mail: rglopez@msu.edu. hypocotyl when the first set of true leaves start to emerge, while baby greens are harvested after the first set of true leaves has developed, generally $\geq 21 \mathrm{~d}$ after germination (Treadwell et al., 2010). Microgreens are mainly used by chefs and consumers to enhance the flavor, color, and texture of various foods (Treadwell et al., 2010). In addition, several species of microgreens contain high concentrations of health-promoting phytochemicals (Xiao et al., 2012). Commercial greenhouse growers have recently become interested in producing microgreens because of their high market value. Wholesale prices currently range from US\$60 to $\$ 100$ per $\mathrm{kg}$ for microgreens packaged in clamshell containers (Resh, 2013; Treadwell et al., 2010). In comparison, the wholesale price of greenhouse-grown boston lettuce (Lactuca sativa L.) packaged in plastic containers was about US\$12 to $\$ 16$ per $\mathrm{kg}$ (United States Department of Agriculture,
2016). Specifically, microgreens of the genus Brassica have become a popular choice due to the ease of germination, relatively short production time ( 7 to $21 \mathrm{~d}$ ), and wide offering of intense flavors and colors (Xiao et al., 2012).

Several commercial growers are currently producing microgreens in greenhouses using soilless media in trays. Microgreens are also produced hydroponically using capillary mats placed in troughs, similar to those used in a nutrient film technique system. Another technique being used is a combination of hydroponics and SS lighting in multilayer vertical growing systems (Resh, 2013). Multilayer vertical growing systems using SS lighting were first developed and implemented commercially in Japan in the early 2000s (Goto, 2012). Although fluorescent lamps were initially used as the standard light source, growers have begun replacing them with LED arrays. Several operations worldwide have implemented this technology as LEDs have become more economically viable due to increased efficiency and decreased cost (Goto, 2012).

Multilayer vertical growing operations have substantial energy costs due to the amount of electricity required for SS lighting and temperature management (Goto, 2012). Light-emitting diodes offer many advantages over conventional light sources, including high photoelectric conversion efficiencies, narrowband spectral distribution, low thermal output, and adjustable LIs (Yeh and Chung, 2009). These advantages may become even more prevalent and defined as technology and research continue to improve.

Another potential advantage of using LEDs is the ability to select light qualities and intensities that have beneficial effects on plant growth and photomorphogenesis (Goto, 2012). The ability to impact growth of microgreens has been recently investigated using SS LEDs at different LIs. Samuoliené et al. (2013) found that increasing the photosynthetic photon flux $(P P F)$ of SS LED lighting with a red:far-red:blue light ratio $(\%)$ of 91:1:8 $\left(\mathrm{R}_{91}: \mathrm{FR}_{1}: \mathrm{B}_{8}\right)$ led to significantly reduced hypocotyl elongation of kohlrabi $(B$. oleracea var. gongylodes 'Delicacy Purple'), tatsoi (B. rapa var. rosularis), and mustard (B. juncea L. 'Red Lion'), and increased percent DW of red pak choi (B. rapa var. chinensis 'Rubi $F_{1}$ ') and tatsoi microgreens. In regard to LQ, Li and Kubota (2009) reported that white light supplemented with far-red light significantly increased fresh weight (FW), DW, stem length, leaf length, and leaf width, compared with white light alone, of baby leaf lettuce 'Red Cross'. An additional study of LQ was conducted by Kopsell and Sams (2013) on broccoli (B. oleracea var. italica Plenck) microgreens $13 \mathrm{~d}$ after sowing. Seeds were placed under either a red:blue light ratio (\%) of $88: 12\left(\mathrm{R}_{88}: \mathrm{B}_{12}\right)$ at a continuous $P P F$ of $350 \mu \mathrm{mol} \cdot \mathrm{m}^{-2} \cdot \mathrm{s}^{-1}$ or $0: 100\left(\mathrm{R}_{0}: \mathrm{B}_{100}\right)$ at $41 \mu \mathrm{mol} \cdot \mathrm{m}^{-2} \cdot \mathrm{s}^{-1}$. Specifically, they found that microgreens grown under the $\mathrm{R}_{0}: \mathrm{B}_{100}$ light ratio produced significantly higher levels of all essential nutrients compared with those grown under $\mathrm{R}_{88}: \mathrm{B}_{12} 19 \mathrm{~d}$ after sowing. 
Although previous reports have indicated that LI or LQ from SS LEDs had an effect on the growth of microgreens and baby greens, to our knowledge, little work has been published on the interaction between LI and LQ on the growth and nutrient content of Brassica microgreens. Therefore, the objective of this study was to quantify the effects of SS LEDs providing different LIs and LQs on the growth, morphology, and nutrient content of Brassica microgreens.

\section{Materials and Methods}

Plant material and culture. A hydroponic tray system for microgreen culture was created using polyethylene terephthalate fiber pads $(50.8 \mathrm{~cm} \times 24.7 \mathrm{~cm} \times 0.89 \mathrm{~cm}$; Sure to Grow, Beachwood, $\mathrm{OH}$ ) placed in trays $(52 \mathrm{~cm} \times 26 \mathrm{~cm} \times 6 \mathrm{~cm})$ without drainage holes. Pads were initially hydrated with $350 \mathrm{~mL}$ of a calcium chloride $\left(\mathrm{CaCl}_{2}\right)$ solution in deionized water to provide $100 \mathrm{mg} \cdot \mathrm{L}^{-1}$ calcium (Ca) to ensure uniform germination. Nine tray systems were established for each species by sowing $25 \mathrm{~g}$ of purple kohlrabi (B. oleracea var. gongylodes L.), $15 \mathrm{~g}$ of mizuna (B. rapa L. var. japonica), or $15 \mathrm{~g}$ of mustard $[B$. juncea (L.) Czern. 'Garnet Giant'] (Johnny's Selected Seeds, Winslow, ME) seeds evenly onto each hydrated pad. For the first $5 \mathrm{~d}$ after sowing, $100 \mathrm{~mL}$ of $\mathrm{CaCl}_{2}$ solution was added to each tray daily to further stimulate seedling growth. Once cotyledons were fully reflexed $5 \mathrm{~d}$ after sowing, $\pm 300 \mathrm{~mL}$ of a $25 \%$ Hoagland's no. 1 nutrient solution (Hoagland and Arnon, 1950) was added to each tray daily to provide (in $\mathrm{mg} \cdot \mathrm{L}^{-1}$ ) 53 nitrogen $(\mathrm{N}), 8$ phosphorus, 59 potassium $(\mathrm{K}), 50 \mathrm{Ca}, 12$ magnesium, 0.5 iron $(\mathrm{Fe}), 0.13$ manganese, 0.01 zinc, 0.005 copper, 0.13 boron (B), and 0.002 molybdenum until harvest.

Growth chamber environment. Trays were placed on stainless steel shelves in three vertical layers in a walk-in growth chamber (C5 Control System; Environmental Growth Chambers, Chagrin Falls, OH) on 28 July, 18 Aug., or 11 Sept. 2014 to germinate in darkness under an average daily temperature, relative humidity $(\mathrm{RH})$, and carbon dioxide $\left(\mathrm{CO}_{2}\right)$ concentration of $21 \pm 0.1{ }^{\circ} \mathrm{C}, 80 \pm 0.5 \%$, and $500 \pm 21 \mu \mathrm{mol} \cdot \mathrm{mol}^{-1}$, respectively. After a 3-d germination period, the air temperature set point was changed to $21{ }^{\circ} \mathrm{C}$ day/ $17{ }^{\circ} \mathrm{C}$ night (D/N; $16 \mathrm{~h} / 8 \mathrm{~h}$ ), the RH set point was changed to $55 / 65 \% \mathrm{D} / \mathrm{N}$, and the $\mathrm{CO}_{2}$ concentration was maintained at $500 \mu \mathrm{mol} \cdot \mathrm{mol}^{-1}$. Average $\mathrm{D} / \mathrm{N}$ air temperatures, $\mathrm{D} / \mathrm{N}$ RHs, and $\mathrm{CO}_{2}$ concentrations were logged every $15 \mathrm{~min}$ by a data logger (DL1 Datalogger; Environmental Growth Chambers) with the mean \pm SD of the combined experimental replications measuring $21.0 \pm 0.1 \mathrm{D} / 17.0 \pm 0.1^{\circ} \mathrm{C} \mathrm{N}, 65.5 \pm 0.6$ $\mathrm{D} / 55.9 \pm 1.0 \% \mathrm{~N}$, and $504.5 \pm 47.8 \mu \mathrm{mol} \cdot \mathrm{mol}^{-1}$, respectively.

SS LED lighting. Light-emitting diode arrays providing light ratios (\%) of red:green: blue 74:18:8 $\left(\mathrm{R}_{74}: \mathrm{G}_{18}: \mathrm{B}_{8}\right)$, red:blue 87:13 $\left(\mathrm{R}_{87}\right.$ : $\left.\mathrm{B}_{13}\right)$, or red:far-red:blue 84:7:9 $\left(\mathrm{R}_{84}: \mathrm{FR}_{7}: \mathrm{B}_{9}\right)$ (Philips GreenPower LED production modules; Koninklijke Philips Electronics, N.V.,
Amsterdam, The Netherlands) were mounted to the underside of nine stainless steel shelves (123 cm long and $61 \mathrm{~cm}$ wide). Nonreflective blackout cloth was used to prevent light pollution between treatments. Average TPF, from 400 to $800 \mathrm{~nm}$, of 105,210 , or $315 \mu \mathrm{mol} \cdot \mathrm{m}^{-2} \cdot \mathrm{s}^{-1}$ was achieved by mounting 2, 4, or 6 arrays, spaced $20.3,12.2$, or $8.6 \mathrm{~cm}$ apart, respectively, $\approx 38 \mathrm{~cm}$ above the crop canopy. A 16-h (0600 to $2200 \mathrm{HR}$ ) photoperiod provided plants with a DLI of 6,12 , or $18 \mathrm{~mol} \cdot \mathrm{m}^{-2} \cdot \mathrm{d}^{-1}$, respectively. Light quality and TPF were measured at the beginning and confirmed at the end of each experimental replication by taking nine individual spectral scans per treatment using a spectroradiometer (PS-100; Apogee Instruments Inc., Logan, UT). The spectral LQ for each of the SS LED treatments is reported in Fig. 1. In addition, average TPF and DLI are reported in Table 1. Kohlrabi was placed under light treatments on 31 July and 21 Aug. 2014. Mizuna and mustard were placed under light treatments on 31 July and 14 Sept. 2014.

Growth and morphology measurements. Growth and morphology data were collected for kohlrabi, mizuna, and mustard, 10, 15, and $14 \mathrm{~d}$ after sowing, respectively. Ten seedlings of each species were randomly selected and measured to determine HL, LA, and total chlorophyll $(a+b)$ content (i.e., RCC) for each SS LED treatment. Hypocotyl length was measured from the base of the hypocotyl to the shoot apical meristem using a digital caliper (DigiMax; Wiha, Schonach, Germany). Leaf area of cotyledons and fully expanded leaves was measured using a LA meter (LI-3100; LI-COR Inc., Lincoln, NE) by recording the average of three scans. Relative chlorophyll content of the cotyledons was measured using a SPAD meter (SPAD-502; Konica Minolta Sensing, Inc., Osaka, Japan). Ten samples, each comprised of 10 randomly selected seedlings per species, were used to determine FW and DW. After FW data were collected, each sample was dried in an oven at $70{ }^{\circ} \mathrm{C}$ for at least $4 \mathrm{~d}$ and DW data were recorded. Fresh weight and DW data were then used to report percent $\mathrm{DW}(\mathrm{DW} / \mathrm{FW} \times 100)$ to reduce variability between the samples collected.

Nutrient analysis. A representative sample of microgreen tissue from each treatment and replication was oven-dried at $70{ }^{\circ} \mathrm{C}$ for at least $4 \mathrm{~d}$, ground into a fine powder with a mortar and pestle, and then divided into two sample fractions. Foliar $\mathrm{N}$ was determined using a $\mathrm{CHN}$ analyzer (PerkinElmer Series II CHNS/O Analyzer; PerkinElmer Instruments, Shelton, CT). For all other elements, plant tissue was microwave digested (MARS; CEM Corp., Matthews, NC) and nutrient concentration was determined using inductively coupled plasma optical emission spectroscopy (ICP-OES; Thermo iCAP 6300; Thermo Electron Corp., Waltham, MA) as described by Frantz (2013).

Experimental design and statistical analysis. The experiment was laid out in a randomized block design in a factorial arrangement with LI (three levels) and LQ (three levels) as factors. The experiment was performed twice over time for each species and data were pooled across replications. The effects of LI and LQ were compared by analysis of variance using SAS (SAS version 9.3; SAS Institute, Cary, NC) PROC MIXED, with an additional program (Arnold M. Saxton, University of Tennessee, Knoxville, TN) that provided pairwise comparisons between treatments using Tukey's honestly significant difference test at $P \leq 0.05$.

\section{Results and Discussion}

Hypocotyl length. Hypocotyl length of kohlrabi, mizuna, and mustard decreased progressively as LI increased (Fig. 2A-C). For example, HL of kohlrabi grown under the light ratio of $\mathrm{R}_{84}: \mathrm{FR}_{7}: \mathrm{B}_{9}$ decreased $32 \%$ as $\mathrm{LI}$ increased from 105 to $315 \mu \mathrm{mol} \cdot \mathrm{m}^{-2} \cdot \mathrm{s}^{-1}$. The role of gibberellins (GA) in the regulation of hypocotyl elongation has been well established. Increased LIs can reduce levels of endogenous GA content in Brassica seedlings, causing inhibition of hypocotyl elongation (Potter et al., 1999). Samuoliené et al. (2013) reported similar reductions in HL of kohlrabi grown under a light ratio of $\mathrm{R}_{91}: \mathrm{FR}_{1}$ : $\mathrm{B}_{8}$. The authors reported that as DLI increased from 6 to $19 \mathrm{~mol} \cdot \mathrm{m}^{-2} \cdot \mathrm{d}^{-1}$, HL of kohlrabi decreased 33\%.

In the current study, HL of kohlrabi, mizuna, and mustard was also significantly influenced by LQ (Table 2). However, the impact of LQ in combination with LI varied by species. Hypocotyl length of mizuna and mustard was only influenced by LQ when grown at a LI of 210 or $315 \mu \mathrm{mol} \cdot \mathrm{m}^{-2} \cdot \mathrm{s}^{-1}$, whereas HL of kohlrabi was only influenced at a LI of $105 \mu \mathrm{mol} \cdot \mathrm{m}^{-2} \cdot \mathrm{s}^{-1}$. When differences were present, HL of kohlrabi, mizuna, and mustard was greater when grown under the light ratio of $\mathrm{R}_{74}: \mathrm{G}_{18}: \mathrm{B}_{8}$ compared with those grown under $\mathrm{R}_{87}: \mathrm{B}_{13}$ or $\mathrm{R}_{84}: \mathrm{FR}_{7}: \mathrm{B}_{9}$ (Fig. 2A-C). For example, HL of mizuna and mustard produced under a LI of $210 \mu \mathrm{mol} \cdot \mathrm{m}^{-2} \cdot \mathrm{s}^{-1}$ and a light ratio of $\mathrm{R}_{74}$ : $\mathrm{G}_{18}: \mathrm{B}_{8}$ was $13 \%$ and $12 \%$ greater, respectively, compared with those grown under $\mathrm{R}_{84}: \mathrm{FR}_{7}: \mathrm{B}_{9}$ (Fig. 2B and C).

Hypocotyl elongation related to $L Q$ is generally caused by a low red:far-red ratio. Red and far-red light are absorbed by phytochrome pigments that exist in two interconvertible forms. Far-red (700 to $800 \mathrm{~nm}$ ) and green light are transmitted through leaf tissue more efficiently than red or blue light, causing enrichment of far-red and green light in plants grown under canopies. When a low ratio of red:far-red light is absorbed by phytochrome pigments, a shade avoidance response is triggered to elongate hypocotyls (Zhang and Folta, 2012). In our study, HL of kohlrabi grown with a LI of $105 \mu \mathrm{mol} \cdot \mathrm{m}^{-2} \cdot \mathrm{s}^{-1}$ and mustard grown with a LI of 315 $\mu \mathrm{mol} \cdot \mathrm{m}^{-2} \cdot \mathrm{s}^{-1}$ and a light ratio of $\mathrm{R}_{84}: \mathrm{FR}_{7}: \mathrm{B}_{9}$ was $11 \%$ and $14 \%$ greater, respectively, compared with those grown under $\mathrm{R}_{87}: \mathrm{B}_{13}$ (Fig. 2A and C). The addition of far-red light in the light ratio of $\mathrm{R}_{84}: \mathrm{FR}_{7}: \mathrm{B}_{9}$ reduced the red:far-red ratio and may have induced a shade avoidance response. 


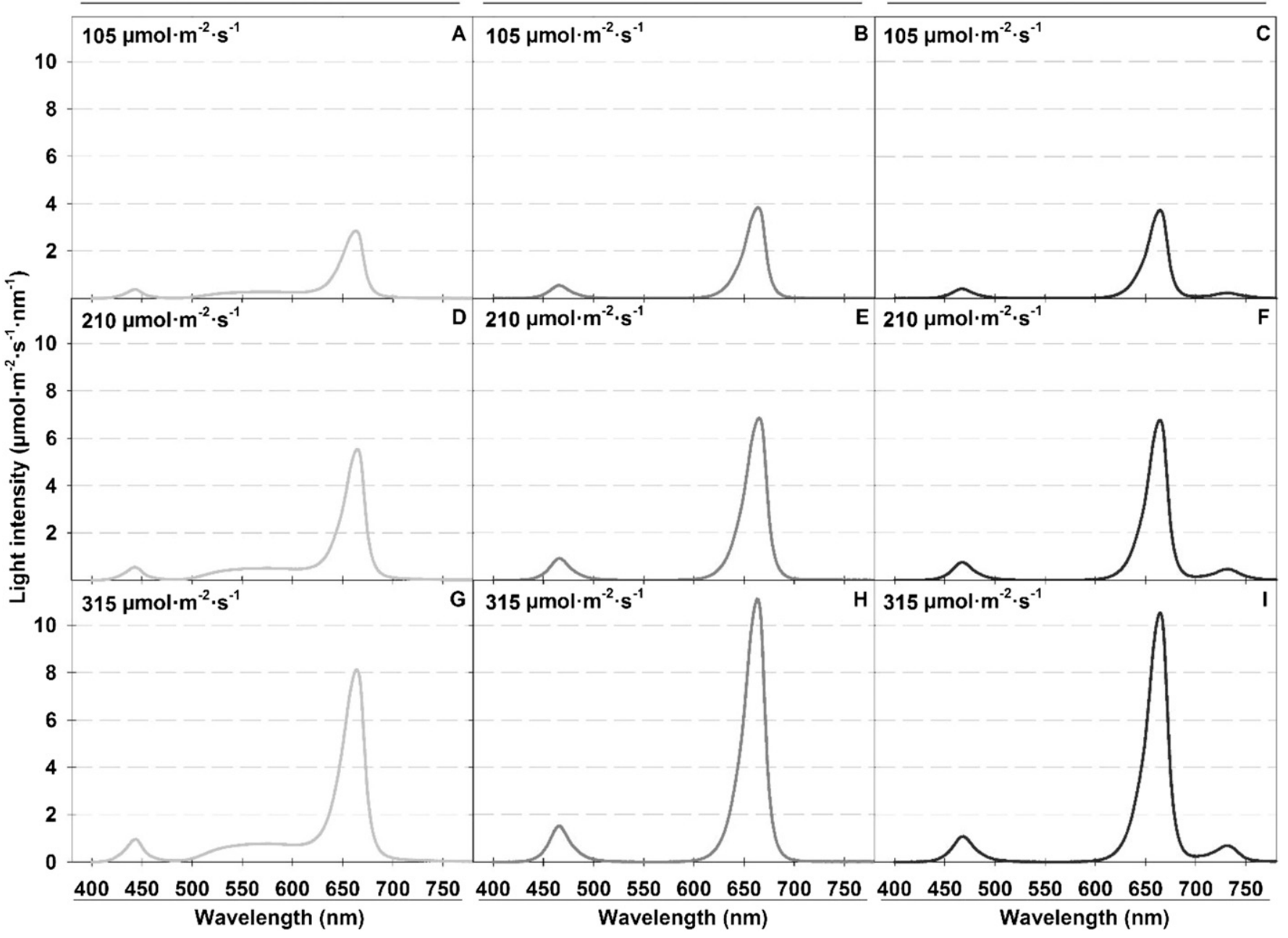

Fig. 1. Spectral quality delivered from sole-source light-emitting diode arrays with light ratios (\%) of red:green:blue 74:18:8 ( $\left.\mathrm{R}_{74}: \mathrm{G}_{18}: \mathrm{B}_{8}\right)$, red:blue $87: 13$ ( $\mathrm{R}_{87}$ : $\left.\mathrm{B}_{13}\right)$, or red:far-red:blue $84: 7: 9\left(\mathrm{R}_{84}: \mathrm{FR}_{7}: \mathrm{B}_{9}\right)$ at a total photon flux from 400 to $800 \mathrm{~nm}$ of 105,210 , or $315 \mu \mathrm{mol} \cdot \mathrm{m}^{-2} \cdot \mathrm{s}^{-1}$ at canopy level.

Table 1. Average total photon flux (TPF) from 400 to $800 \mathrm{~nm} \pm$ sD delivered from sole-source light-emitting diodes with light ratios (\%) of red:green:blue $74: 18: 8\left(\mathrm{R}_{74}: \mathrm{G}_{18}: \mathrm{B}_{8}\right)$, red:blue $87: 13\left(\mathrm{R}_{87}: \mathrm{B}_{13}\right)$, or red:far-red:blue 84:7:9 $\left(\mathrm{R}_{84}: \mathrm{FR}_{7}: \mathrm{B}_{9}\right)$ to achieve target light intensities (LIs) of 105, 210, and $315 \mu \mathrm{mol} \cdot \mathrm{m}^{-2} \cdot \mathrm{s}^{-1}$. The average daily light integrals (DLIs), measured from 400 to $800 \mathrm{~nm}$, under a 16-h photoperiod ( 0600 to $2200 \mathrm{HR}$ ) are also reported. Mean values reported are the average of nine spectral scans across three replications.

\begin{tabular}{lccc}
\hline $\begin{array}{l}\text { Light intensity } \\
\text { treatment }\left(\mu \mathrm{mol} \cdot \mathrm{m}^{-2} \cdot \mathrm{s}^{-1}\right)\end{array}$ & $\begin{array}{c}\text { Light quality } \\
\text { treatment }(\%)\end{array}$ & Avg TPF $\left(\mu \mathrm{mol} \cdot \mathrm{m}^{-2} \cdot \mathrm{s}^{-1}\right)$ & Avg DLI $\left(\mathrm{mol} \cdot \mathrm{m}^{-2} \cdot \mathrm{d}^{-1}\right)$ \\
\hline 105 & $\mathrm{R}_{74}: \mathrm{G}_{18}: \mathrm{B}_{8}$ & $108.2 \pm 23.7$ & $6.2 \pm 1.4$ \\
& $\mathrm{R}_{87}: \mathrm{B}_{13}$ & $110.8 \pm 25.2$ & $6.4 \pm 1.4$ \\
& $\mathrm{R}_{84}: \mathrm{FR}_{7}: \mathrm{B}_{9}$ & $108.4 \pm 22.8$ & $6.2 \pm 1.3$ \\
& $\mathrm{R}_{74}: \mathrm{G}_{18}: \mathrm{B}_{8}$ & $215.1 \pm 33.6$ & $12.4 \pm 1.9$ \\
& $\mathrm{R}_{87}: \mathrm{B}_{13}$ & $210.2 \pm 31.4$ & $12.1 \pm 1.8$ \\
& $\mathrm{R}_{84}: \mathrm{FR}_{7}: \mathrm{B}_{9}$ & $207.6 \pm 33.2$ & $12.0 \pm 1.9$ \\
315 & $\mathrm{R}_{74}: \mathrm{G}_{18}: \mathrm{B}_{8}$ & $312.9 \pm 54.4$ & $18.0 \pm 3.1$ \\
& $\mathrm{R}_{87}: \mathrm{B}_{13}$ & $313.2 \pm 53.9$ & $18.0 \pm 3.1$ \\
& $\mathrm{R}_{84}: \mathrm{FR}_{7}: \mathrm{B}_{9}$ & $310.6 \pm 50.9$ & $17.9 \pm 2.9$ \\
\hline
\end{tabular}

In addition to far-red light, the proportion of light in the green waveband could be a possible explanation for hypocotyl elongation in our study. Light in the blue spectral range in combination with red light has been reported to inhibit extension growth of many species (Wollaeger and Runkle, 2014). However, green light in combination with red and blue light has been shown to reverse blue-light inhibition of hypocotyl elongation. The mechanisms responsible for this are believed to be mediated through cryptochrome blue-light receptors (Zhang and Folta, 2012). In addition, Folta (2004) reported that hypocotyl elongation of Arabidopsis thaliana grown under red, blue, or far-red light was suppressed within minutes compared with dark-grown seedlings. However, seedlings grown under monochromatic green light had increased hypocotyl elongation compared with darkgrown seedlings (Folta, 2004). The proportion of green light in the light ratio of $\mathrm{R}_{74}: \mathrm{G}_{18}: \mathrm{B}_{8}$ may have resulted in a similar response. Green light absorbed by cryptochrome has been shown to cause responses similar to the shade avoidance response, although the mechanisms are not fully understood (Zhang and Folta, 2012). Although there have been extensive studies conducted concerning the influence of LQ on HL of individual seedlings, limited work has been published on Brassica microgreens, which are typically grown in high densities.

Leaf area. In our study, the interaction between LI and LQ was not significant for LA in any of the three species. However, LA of kohlrabi and mustard was significantly influenced by the main effect of LI (Table 2). Specifically, LA of kohlrabi and mustard decreased as LI increased. For example, as LI increased from 105 to $315 \mu \mathrm{mol} \cdot \mathrm{m}^{-2} \cdot \mathrm{s}^{-1}$, LA of kohlrabi decreased from 1.52 to $1.14 \mathrm{~cm}^{2}$ ( $25 \%$ decrease), and mustard decreased from 1.50 to $1.30 \mathrm{~cm}^{2}$ (13\% decrease). This finding 


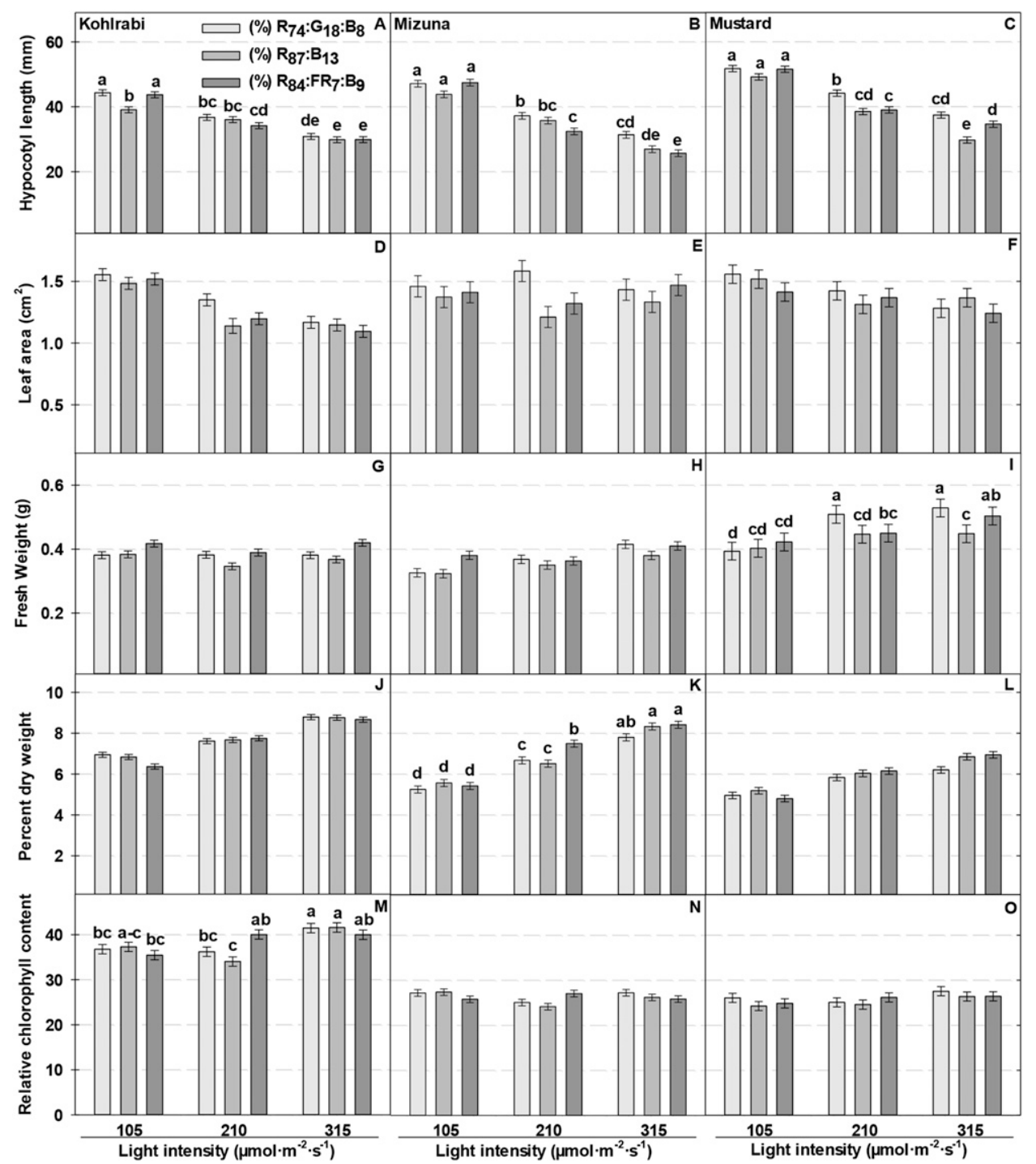

Fig. 2. Hypocotyl length $(\mathbf{A}-\mathbf{C})$, leaf area $(\mathbf{D}-\mathbf{F})$, fresh weight $(\mathbf{G}-\mathbf{I})$, percent dry weight (dry weight/fresh weight $\times 100)(\mathbf{J}-\mathbf{L})$, and relative chlorophyll content (M-O) of kohlrabi (Brassica oleracea L. var. gongylodes L.), mizuna (B. rapa L. var. japonica), and mustard [B. juncea (L.) Czern. 'Garnet Giant'] microgreens placed under light intensities (LIs) of 105, 210, or $315 \mathrm{mmol} \cdot \mathrm{m}^{-2} \cdot \mathrm{s}^{-1}$ delivered from sole-source light-emitting diodes with light ratios (\%) of red:green:blue 74:18:8 $\left(\mathrm{R}_{74}: \mathrm{G}_{18}: \mathrm{B}_{8}\right)$, red:blue 87:13 $\left(\mathrm{R}_{87}: \mathrm{B}_{13}\right)$, or red:far-red:blue 84:7:9 $\left(\mathrm{R}_{84}: \mathrm{FR}_{7}: \mathrm{B}_{9}\right)$. Error bars indicate \pm SE. Means sharing a letter are not statistically different by Tukey's honestly significant difference test at $P \leq 0.05$. Figures with no letter were found to have no significant interaction between LI and light quality.

Table 2. Analysis of variance for the effects of light intensity (LI), light quality (LQ), or LI $\times$ LQ from solesource light-emitting diodes on growth and morphology of kohlrabi (Brassica oleracea L. var. gongylodes L.), mizuna (Brassica rapa L. var. japonica), and mustard [Brassica juncea (L.) Czern. 'Garnet Giant'] microgreens.

\begin{tabular}{|c|c|c|c|c|c|c|c|c|c|}
\hline \multirow[b]{2}{*}{ Data } & \multicolumn{3}{|c|}{ Kohlrabi } & \multicolumn{3}{|c|}{ Mizuna } & \multicolumn{3}{|c|}{ Mustard } \\
\hline & LI & LQ & $\mathrm{LI} \times \mathrm{LQ}$ & LI & LQ & $\mathrm{LI} \times \mathrm{LQ}$ & LI & LQ & $\mathrm{LI} \times \mathrm{LQ}$ \\
\hline Hypocotyl length & $* * *$ & $* *$ & $* *$ & $* * *$ & $* * *$ & $* *$ & $* * *$ & $* * *$ & $*$ \\
\hline Leaf area & $* * *$ & $*$ & NS & NS & $*$ & NS & $* *$ & NS & NS \\
\hline Fresh weight & $*$ & $* * *$ & NS & $* * *$ & $* *$ & NS & $* * *$ & $* * *$ & $* *$ \\
\hline Percent dry weight & $* * *$ & NS & NS & $* * *$ & $* *$ & $*$ & $* * *$ & $*$ & NS \\
\hline Relative chlorophyll & $* * *$ & NS & $* *$ & NS & NS & NS & NS & NS & NS \\
\hline
\end{tabular}

NS, $* * *, * * *$ Nonsignificant or significant at $P \leq 0.05,0.01$, or 0.001 , respectively.

coincides with previous research that reported the LA of seedlings generally increased when grown under low LIs (Jarvis, 1964).

In addition, the LA of kohlrabi and mizuna was significantly impacted by the main effect of LQ (Table 2). The LA of kohlrabi and mizuna microgreens grown under a light ratio of $\mathrm{R}_{74}: \mathrm{G}_{18}: \mathrm{B}_{8}$ increased from 1.26 to $1.36 \mathrm{~cm}^{2}$ ( $7 \%$ increase) and from 1.31 to $1.49 \mathrm{~cm}^{2}(12 \%$ increase), respectively, compared with those grown under $\mathrm{R}_{87}: \mathrm{B}_{13}$. This finding contrasts what was observed for HL under the light ratio of $\mathrm{R}_{74}: \mathrm{G}_{18}: \mathrm{B}_{8}$, as the green light-induced shade avoidance mechanism observed for
HL can elicit reductions in LA (Zhang and Folta, 2012). Thus, if the addition of green light was indeed initiating a similar response to that observed with decreasing red:far-red ratios, a decrease in LA would have been expected. Although green light is believed to elicit photomorphogenic responses similar to shade avoidance, further research is needed to better understand this mechanism and the associated changes in plant growth (Zhang and Folta, 2012).

$F W$ and percent $D W$. In our study, FW and percent DW of all species generally increased as LI increased (Fig. 2G-L). Fresh weight of mustard grown under light ratios of $\mathrm{R}_{74}: \mathrm{G}_{18}: \mathrm{B}_{8}$ and $\mathrm{R}_{84}: \mathrm{FR}_{7}: \mathrm{B}_{9}$ increased $34 \%$ and $19 \%$, respectively, as LI increased from 105 to $315 \mu \mathrm{mol} \cdot \mathrm{m}^{-2} \cdot \mathrm{s}^{-1}$ (Fig. 2I). In addition, FW of mizuna increased $15 \%$ as LI increased from 105 to $315 \mu \mathrm{mol} \cdot \mathrm{m}^{-2} \cdot \mathrm{s}^{-1}$, regardless of LQ. Similarly, percent DW of kohlrabi and 
mustard increased from $6.7 \%$ to $8.7 \%$ and from $5.0 \%$ to $6.7 \%$, respectively, as LI increased from 105 to $315 \mu \mathrm{mol} \cdot \mathrm{m}^{-2} \cdot \mathrm{s}^{-1}$, regardless of LQ. Samuoliené et al. (2013) also reported similar increases in percent DW of tatsoi and red pak choi microgreens as DLI increased from 6 to $19 \mathrm{~mol} \cdot \mathrm{m}^{-2} \cdot \mathrm{d}^{-1}$. Plant growth, defined as an irreversible increase in plant size, is a function of biomass production driven by photosynthesis (Heins et al., 2000). Thus, the response observed in this study was expected as the treatments with the higher LIs provided additional light for photosynthetic activity and, as a result, biomass accumulation.

The main effect of LQ on FW was significant for kohlrabi and mizuna. Generally, FW was greater when grown under a light ratio of $\mathrm{R}_{84}: \mathrm{FR}_{7}: \mathrm{B}_{9}$ compared with those grown under $\mathrm{R}_{87}: \mathrm{B}_{13}$ (Fig. 2G-I). For example, FW of kohlrabi and mizuna was $9.8 \%$ and $7.9 \%$ greater, respectively, under the ratio $\mathrm{R}_{84}: \mathrm{FR}_{7}$ : $\mathrm{B}_{9}$ compared with $\mathrm{R}_{87}: \mathrm{B}_{13}$. In addition, $\mathrm{FW}$ of mustard grown with a light ratio of $\mathrm{R}_{74}: \mathrm{G}_{18}: \mathrm{B}_{8}$ and a LI of 210 or $315 \mu \mathrm{mol} \cdot \mathrm{m}^{-2} \cdot \mathrm{s}^{-1}$ was $14 \%$ or $18 \%$ greater, respectively, compared with those grown under $\mathrm{R}_{87}: \mathrm{B}_{13}$ (Fig. 2I), but not different across LQ at a LI of $105 \mu \mathrm{mol} \cdot \mathrm{m}^{-2} \cdot \mathrm{s}^{-1}$.

In our study, percent DW of kohlrabi was not influenced by LQ. However, the impact of LQ on percent DW of mizuna varied with LI. Light quality did not affect DW at low or high LI $\left(105\right.$ or $\left.315 \mu \mathrm{mol} \cdot \mathrm{m}^{-2} \cdot \mathrm{s}^{-1}\right)$, but percent DW of mizuna grown under a LI of $210 \mu \mathrm{mol} \cdot \mathrm{m}^{-2} \cdot \mathrm{s}^{-1}$ with a light ratio of $\mathrm{R}_{84}$ : $\mathrm{FR}_{7}: \mathrm{B}_{9}$ was $1.0 \%$ and $0.8 \%$ higher than those grown under $R_{87}: B_{13}$ and $R_{74}: G_{18}: B_{8}$, respectively (Fig. $2 \mathrm{~K}$ ). In addition, the main effect of LQ for percent DW of mustard was significant. The light ratio of $\mathrm{R}_{87}: \mathrm{B}_{13}$ produced $6.02 \%$ DW, $0.36 \%$ higher than those grown under a light ratio of $\mathrm{R}_{74}: \mathrm{G}_{18}: \mathrm{B}_{8}$ $(5.66 \%$ DW). Limited work has been published on Brassica microgreens to investigate the effects of LQ on biomass accumulation. Kopsell et al. (2014) observed that broccoli microgreens displayed no significant changes in DW under light ratios of $\mathrm{R}_{95}: \mathrm{B}_{5}, \mathrm{R}_{85}: \mathrm{G}_{10}$ : $\mathrm{B}_{5}, \mathrm{R}_{80}: \mathrm{B}_{20}, \mathrm{R}_{70}: \mathrm{G}_{10}: \mathrm{B}_{20}$, or fluorescent/ incandescent lamps providing a $P P F$ of 250 $\mu \mathrm{mol} \cdot \mathrm{m}^{-2} \cdot \mathrm{s}^{-1}$. However, the FW of broccoli microgreens produced under light ratios of $\mathrm{R}_{85}: \mathrm{G}_{10}: \mathrm{B}_{5}$ and $\mathrm{R}_{80}: \mathrm{B}_{20}$ were significantly higher than those produced under $\mathrm{R}_{70}: \mathrm{G}_{10}$ : $\mathrm{B}_{20}$ or fluorescent/incandescent lamps. $\mathrm{Li}$ and Kubota (2009) reported that LQ had significant effects on FW and DW of leaf lettuce harvested $25 \mathrm{~d}$ after germination at the 'baby green' growth stage. The FW and DW of baby leaf lettuce significantly increased when grown under SS fluorescent white light supplemented with far-red LEDs compared with fluorescent white light as a control or fluorescent white lights supplemented with ultraviolet-A or red LEDs. In that study, while the $P P F$ was $305 \mu \mathrm{mol} \cdot \mathrm{m}^{-2} \cdot \mathrm{s}^{-1}$ for all treatments, the far-red LEDs provided an additional $160 \mu \mathrm{mol} \cdot \mathrm{m}^{-2} \cdot \mathrm{s}^{-1}$ of light. Recent in vitro studies using spinach (Spinacia oleracea L.) and in vivo studies using sunflower (Helianthus annuus L.) and bean (Phaseolus vulgaris L.) have reported that far-red light, up to $790 \mathrm{~nm}$, can drive photosynthetic activity in photosystem II (PSII) (Pettai et al., 2005; Thapper et al., 2009). Increased photosynthetic activity of baby leaf lettuce may have occurred due to the additional $160 \mu \mathrm{mol} \cdot \mathrm{m}^{-2} \cdot \mathrm{s}^{-1}$ of far-red light, resulting in increased FW and DW. In the present study, TPF was measured from 400 to $800 \mathrm{~nm}$ to include light qualities in the far-red range to ensure LI was consistent among SS LED light treatments. Our results and those by Li and Kubota (2009) indicate that more studies are needed to clarify how far-red light in SS lighting scenarios impacts biomass accumulation of Brassica microgreens and baby leaf lettuce.

Relative chlorophyll content. Relative chlorophyll content of mizuna and mustard was not significantly influenced by LI or LQ (Table 2). However, RCC of kohlrabi under a light ratio of $\mathrm{R}_{74}: \mathrm{G}_{18}: \mathrm{B}_{8}$ and a LI of 315 $\mu \mathrm{mol} \cdot \mathrm{m}^{-2} \cdot \mathrm{s}^{-1}$ increased by $11 \%$ or $13 \%$ compared with those provided a LI of 105 or $210 \mu \mathrm{mol} \cdot \mathrm{m}^{-2} \cdot \mathrm{s}^{-1}$, respectively (Fig. $2 \mathrm{M}$ ). In addition, RCC of kohlrabi grown with a LI of $210 \mu \mathrm{mol} \cdot \mathrm{m}^{-2} \cdot \mathrm{s}^{-1}$ and a light ratio of $\mathrm{R}_{84}$ : $\mathrm{FR}_{7}: \mathrm{B}_{9}$ increased $15 \%$ compared with those under $\mathrm{R}_{87}: \mathrm{B}_{13}$ (Fig. 2M). Samuoliené et al. (2013) reported similar results in terms of LI with an $11 \%$ increase in RCC of mustard grown with a light ratio of $\mathrm{R}_{91}: \mathrm{FR}_{1}: \mathrm{B}_{8}$ and a $P P F$ of $545 \mu \mathrm{mol} \cdot \mathrm{m}^{-2} \cdot \mathrm{s}^{-1}$ compared with those grown under the same light ratio with a $P P F$ of $220 \mu \mathrm{mol} \cdot \mathrm{m}^{-2} \cdot \mathrm{s}^{-1}$. However, the majority of the results presented from the present study show relatively stable RCC levels across treatments.

Nutrient content. Generally, for all three Brassica species in the current study, nutrient concentration of both macro- and micronutrients decreased as LI increased (Tables 3 and 4). This trend may be the result of a dilution of nutrients due to the increased percent DW observed at higher LIs (Fig. 2J-L). This

Table 3. Macronutrient concentration [percent dry weight (DW)] of kohlrabi (Brassica oleracea L. var. gongylodes L.), mizuna (Brassica rapa L. var. japonica), and mustard [Brassica juncea (L.) Czern. 'Garnet Giant'] microgreens placed under light intensities (LIs) of 105,210 , or $315 \mu \mathrm{mol} \cdot \mathrm{m}^{-2} \cdot \mathrm{s}^{-1}$ delivered from sole-source light-emitting diodes (LEDs) with light quality (LQ) ratios (\%) of red: green:blue 74:18:8 $\left(\mathrm{R}_{74}: \mathrm{G}_{18}: \mathrm{B}_{8}\right)$, red:blue $87: 13\left(\mathrm{R}_{87}: \mathrm{B}_{13}\right)$, or red:far-red:blue 84:7:9 $\left(\mathrm{R}_{84}: \mathrm{FR}_{7}: \mathrm{B}_{9}\right)$.

\begin{tabular}{|c|c|c|c|c|c|c|c|}
\hline \multirow[b]{2}{*}{ LI } & \multirow[b]{2}{*}{ LED } & \multicolumn{6}{|c|}{ Macronutrients (percent DW) } \\
\hline & & Nitrogen & Phosphorus & Potassium & Sulfur & Calcium & Magnesium \\
\hline & & \multicolumn{6}{|c|}{ Kohlrabi } \\
\hline \multirow[t]{3}{*}{105} & $\mathrm{R}_{74}: \mathrm{G}_{18}: \mathrm{B}_{8}$ & $5.25^{z}$ & 1.17 & 1.22 & 1.75 & 2.01 & 0.56 \\
\hline & $\mathrm{R}_{87}: \mathrm{B}_{13}$ & 5.41 & 1.21 & 1.26 & 1.83 & 2.02 & 0.57 \\
\hline & $\mathrm{R}_{84}: \mathrm{FR}_{7}: \mathrm{B}_{9}$ & 5.41 & 1.18 & 1.33 & 1.78 & 2.13 & 0.58 \\
\hline \multirow[t]{3}{*}{210} & $\mathrm{R}_{74}: \mathrm{G}_{18}: \mathrm{B}_{8}$ & 4.83 & 1.10 & 0.89 & 1.62 & 1.72 & 0.49 \\
\hline & $\mathrm{R}_{87}: \mathrm{B}_{13}$ & 4.75 & 1.11 & 0.93 & 1.58 & 1.73 & 0.50 \\
\hline & $\mathrm{R}_{84}: \mathrm{FR}_{7}: \mathrm{B}_{9}$ & 4.69 & 1.08 & 0.95 & 1.57 & 1.89 & 0.51 \\
\hline \multirow[t]{3}{*}{315} & $\mathrm{R}_{74}: \mathrm{G}_{18}: \mathrm{B}_{8}$ & 4.30 & 0.97 & 0.84 & 1.46 & 1.77 & 0.48 \\
\hline & $\mathrm{R}_{87}: \mathrm{B}_{13}$ & 4.38 & 0.97 & 0.78 & 1.43 & 1.69 & 0.48 \\
\hline & $\mathrm{R}_{84}: \mathrm{FR}_{7}: \mathrm{B}_{9}$ & 4.23 & 0.96 & 0.97 & 1.42 & 1.86 & 0.49 \\
\hline LQ & & NS & NS & $* *$ & NS & $* *$ & NS \\
\hline LI & & $* * *$ & $* * *$ & $* * *$ & $* * *$ & $* * *$ & $* * *$ \\
\hline \multirow[t]{2}{*}{$\mathrm{LQ} \times \mathrm{LI}$} & & NS & NS & NS & NS & NS & NS \\
\hline & & \multicolumn{6}{|c|}{ Mizuna } \\
\hline \multirow[t]{3}{*}{105} & $\mathrm{R}_{74}: \mathrm{G}_{18}: \mathrm{B}_{8}$ & $4.30 \mathrm{a}^{\mathrm{y}}$ & 1.01 & $1.88 \mathrm{a}$ & 1.19 & $2.88 \mathrm{a}$ & 0.73 \\
\hline & $\mathrm{R}_{87}: \mathrm{B}_{13}$ & $3.88 \mathrm{a}$ & 0.96 & $1.77 \mathrm{a}$ & 1.12 & $2.75 \mathrm{a}$ & 0.70 \\
\hline & $\mathrm{R}_{84}: \mathrm{FR}_{7}: \mathrm{B}_{9}$ & $4.00 \mathrm{a}$ & 0.97 & $1.98 \mathrm{a}$ & 1.17 & $2.89 \mathrm{a}$ & 0.71 \\
\hline \multirow[t]{3}{*}{210} & $\mathrm{R}_{74}: \mathrm{G}_{18}: \mathrm{B}_{8}$ & $3.23 \mathrm{~b}$ & 0.76 & $1.44 \mathrm{~b}$ & 0.91 & $2.17 \mathrm{~b}$ & 0.58 \\
\hline & $\mathrm{R}_{87}: \mathrm{B}_{13}$ & $3.20 \mathrm{~b}$ & 0.75 & $1.42 \mathrm{~b}$ & 0.89 & $2.13 \mathrm{~b}$ & 0.57 \\
\hline & $\mathrm{R}_{84}: \mathrm{FR}_{7}: \mathrm{B}_{9}$ & $2.58 \mathrm{~cd}$ & 0.69 & $1.20 \mathrm{~d}$ & 0.83 & $2.15 \mathrm{~b}$ & 0.54 \\
\hline \multirow[t]{3}{*}{315} & $\mathrm{R}_{74}: \mathrm{G}_{18}: \mathrm{B}_{8}$ & $2.69 \mathrm{c}$ & 0.62 & $1.41 \mathrm{bc}$ & 0.78 & $2.16 \mathrm{~b}$ & 0.54 \\
\hline & $\mathrm{R}_{87}: \mathrm{B}_{13}$ & $2.56 \mathrm{~cd}$ & 0.59 & $1.21 \mathrm{~cd}$ & 0.74 & $2.03 \mathrm{bc}$ & 0.50 \\
\hline & $\mathrm{R}_{84}: \mathrm{FR}_{7}: \mathrm{B}_{9}$ & $2.21 \mathrm{~d}$ & 0.60 & $1.18 \mathrm{~d}$ & 0.76 & $1.89 \mathrm{c}$ & 0.48 \\
\hline LQ & & $* * *$ & NS & $* *$ & NS & $* *$ & $* *$ \\
\hline LI & & $* * *$ & $* * *$ & $* * *$ & $* * *$ & $* * *$ & $* * *$ \\
\hline \multirow[t]{2}{*}{$\mathrm{LQ} \times \mathrm{LI}$} & & $* *$ & NS & $* *$ & NS & $* *$ & NS \\
\hline & & \multicolumn{6}{|c|}{ Mustard } \\
\hline \multirow[t]{3}{*}{105} & $\mathrm{R}_{74}: \mathrm{G}_{18}: \mathrm{B}_{8}$ & 4.63 & 0.94 & $1.27 \mathrm{~b}$ & 1.20 & $2.32 \mathrm{a}$ & $0.71 \mathrm{ab}$ \\
\hline & $\mathrm{R}_{87}: \mathrm{B}_{13}$ & 4.29 & 0.86 & $1.24 \mathrm{~b}$ & 1.17 & $2.32 \mathrm{a}$ & $0.66 \mathrm{~b}$ \\
\hline & $\mathrm{R}_{84}: \mathrm{FR}_{7}: \mathrm{B}_{9}$ & 4.50 & 0.93 & $1.44 \mathrm{a}$ & 1.25 & $2.44 \mathrm{a}$ & $0.74 \mathrm{a}$ \\
\hline \multirow[t]{3}{*}{210} & $\mathrm{R}_{74}: \mathrm{G}_{18}: \mathrm{B}_{8}$ & 3.53 & 0.71 & $1.13 \mathrm{bc}$ & 0.93 & $1.94 \mathrm{~b}$ & $0.56 \mathrm{c}$ \\
\hline & $\mathrm{R}_{87}: \mathrm{B}_{13}$ & 3.41 & 0.66 & $1.01 \mathrm{~cd}$ & 0.87 & $1.79 \mathrm{bcd}$ & $0.53 \mathrm{~cd}$ \\
\hline & $\mathrm{R}_{84}: \mathrm{FR}_{7}: \mathrm{B}_{9}$ & 3.32 & 0.68 & $1.01 \mathrm{~cd}$ & 0.87 & $1.80 \mathrm{bcd}$ & $0.53 \mathrm{~cd}$ \\
\hline \multirow[t]{3}{*}{315} & $\mathrm{R}_{74}: \mathrm{G}_{18}: \mathrm{B}_{8}$ & 3.26 & 0.62 & $1.15 \mathrm{bc}$ & 0.81 & $1.94 \mathrm{bc}$ & $0.52 \mathrm{~cd}$ \\
\hline & $\mathrm{R}_{87}: \mathrm{B}_{13}$ & 3.04 & 0.61 & $0.92 \mathrm{~d}$ & 0.76 & $1.74 \mathrm{~cd}$ & $0.50 \mathrm{~cd}$ \\
\hline & $\mathrm{R}_{84}: \mathrm{FR}_{7}: \mathrm{B}_{9}$ & 2.85 & 0.56 & $0.91 \mathrm{~d}$ & 0.72 & $1.72 \mathrm{~d}$ & $0.48 \mathrm{~d}$ \\
\hline LQ & & $*$ & $*$ & $* *$ & NS & $*$ & NS \\
\hline $\mathrm{LI}$ & & $* * *$ & $* * *$ & $* * *$ & $* * *$ & $* * *$ & $* * *$ \\
\hline $\mathrm{LQ} \times \mathrm{LI}$ & & NS & NS & $* * *$ & NS & $* *$ & $*$ \\
\hline
\end{tabular}

${ }^{\mathrm{z}}$ Mean values are based on a representative sample from each treatment across two experimental replications. ${ }^{y}$ Means sharing a letter are not statistically different by Tukey's honestly significant difference test at $P \leq$ 0.05. Means with no lettering were found to have no significant interaction between LI and LQ. NS, $*, * *, * * *$ Nonsignificant or significant at $P \leq 0.05,0.01$, or 0.001 , respectively. 
Table 4. Micronutrient concentrations ( $\mathrm{mg} \cdot \mathrm{kg}^{-1}$ ) of kohlrabi (Brassica oleracea L. var. gongylodes L.), mizuna (Brassica rapa L. var. japonica), and mustard [Brassica juncea (L.) Czern. 'Garnet Giant'] microgreens placed under light intensities (LIs) of 105,210 , or $315 \mu \mathrm{mol} \cdot \mathrm{m}^{-2} \cdot \mathrm{s}^{-1}$ delivered from solesource light-emitting diodes (LEDs) with light quality (LQ) ratios (\%) of red:green:blue 74:18:8 $\left(\mathrm{R}_{74}\right.$ : $\left.\mathrm{G}_{18}: \mathrm{B}_{8}\right)$, red:blue 87:13 $\left(\mathrm{R}_{87}: \mathrm{B}_{13}\right)$, or red:far-red:blue 84:7:9 $\left(\mathrm{R}_{84}: \mathrm{FR}_{7}: \mathrm{B}_{9}\right)$.

\begin{tabular}{|c|c|c|c|c|c|c|}
\hline \multirow[b]{2}{*}{$\underline{\mathrm{LI}}$} & \multirow[b]{2}{*}{ LED } & \multicolumn{5}{|c|}{ Micronutrients $\left(\mathrm{mg} \cdot \mathrm{kg}^{-1}\right)$} \\
\hline & & Boron & Copper & Iron & Manganese & Zinc \\
\hline & & & & Kohlrab & & \\
\hline \multirow{3}{*}{105} & $\mathrm{R}_{74}: \mathrm{G}_{18}: \mathrm{B}_{8}$ & $45.49^{z} c^{y}$ & 5.87 & $120.57 \mathrm{a}$ & 57.26 & 67.28 \\
\hline & $\mathrm{R}_{87}: \mathrm{B}_{13}$ & $48.35 \mathrm{ab}$ & 5.91 & $111.78 a b c$ & 57.49 & 64.89 \\
\hline & $\mathrm{R}_{84}: \mathrm{FR}_{7}: \mathrm{B}_{9}$ & $49.49 \mathrm{a}$ & 5.94 & $119.76 \mathrm{ab}$ & 56.32 & 62.10 \\
\hline \multirow[t]{3}{*}{210} & $\mathrm{R}_{74}: \mathrm{G}_{18}: \mathrm{B}_{8}$ & $41.92 \mathrm{~d}$ & 5.87 & $102.83 \mathrm{cde}$ & 50.03 & 56.67 \\
\hline & $\mathrm{R}_{87}: \mathrm{B}_{13}$ & $46.40 \mathrm{bc}$ & 5.89 & $99.96 \mathrm{de}$ & 51.71 & 56.22 \\
\hline & $\mathrm{R}_{84}: \mathrm{FR}_{7}: \mathrm{B}_{9}$ & $39.69 \mathrm{de}$ & 5.47 & $108.89 \mathrm{bcd}$ & 51.94 & 52.42 \\
\hline \multirow[t]{3}{*}{315} & $\mathrm{R}_{74}: \mathrm{G}_{18}: \mathrm{B}_{8}$ & $45.12 \mathrm{c}$ & 4.85 & $109.52 \mathrm{bcd}$ & 49.18 & 45.94 \\
\hline & $\mathrm{R}_{87}: \mathrm{B}_{13}$ & $39.38 \mathrm{e}$ & 5.01 & $107.78 \mathrm{~cd}$ & 48.02 & 46.94 \\
\hline & $\mathrm{R}_{84}: \mathrm{FR}_{7}: \mathrm{B}_{9}$ & $39.08 \mathrm{e}$ & 4.45 & 93.87 e & 51.35 & 43.91 \\
\hline LQ & & $* *$ & NS & NS & NS & * \\
\hline LI & & $* * *$ & $* * *$ & $* * *$ & $* * *$ & $* * *$ \\
\hline \multirow[t]{2}{*}{$\mathrm{LQ} \times \mathrm{LI}$} & & $* * *$ & NS & $* * *$ & NS & NS \\
\hline & & & & Mizuna & & \\
\hline \multirow[t]{3}{*}{105} & $\mathrm{R}_{74}: \mathrm{G}_{18}: \mathrm{B}_{8}$ & 80.40 & 8.15 & 159.98 & 96.63 & $51.27 \mathrm{ab}$ \\
\hline & $\mathrm{R}_{87}: \mathrm{B}_{13}$ & 75.47 & 7.55 & 129.14 & 93.21 & $54.07 \mathrm{a}$ \\
\hline & $\mathrm{R}_{84}: \mathrm{FR}_{7}: \mathrm{B}_{9}$ & 60.06 & 7.64 & 127.26 & 88.73 & $48.88 \mathrm{abc}$ \\
\hline \multirow[t]{3}{*}{210} & $\mathrm{R}_{74}: \mathrm{G}_{18}: \mathrm{B}_{8}$ & 58.79 & 6.69 & 103.36 & 73.69 & $50.41 \mathrm{abc}$ \\
\hline & $\mathrm{R}_{87}: \mathrm{B}_{13}$ & 62.07 & 5.76 & 98.46 & 74.08 & 39.62 cde \\
\hline & $\mathrm{R}_{84}: \mathrm{FR}_{7}: \mathrm{B}_{9}$ & 46.81 & 6.14 & 106.89 & 70.91 & $42.15 \mathrm{bcd}$ \\
\hline \multirow[t]{3}{*}{315} & $\mathrm{R}_{74}: \mathrm{G}_{18}: \mathrm{B}_{8}$ & 53.21 & 5.69 & 114.82 & 63.73 & $30.66 \mathrm{e}$ \\
\hline & $\mathrm{R}_{87}: \mathrm{B}_{13}$ & 45.27 & 5.84 & 97.48 & 60.93 & $35.66 \mathrm{de}$ \\
\hline & $\mathrm{R}_{84}: \mathrm{FR}_{7}: \mathrm{B}_{9}$ & 26.09 & 5.71 & 80.20 & 58.87 & 40.31 bcde \\
\hline LQ & & $* * *$ & NS & $* *$ & NS & NS \\
\hline LI & & $* * *$ & $* * *$ & $* * *$ & $* * *$ & $* * *$ \\
\hline \multirow[t]{2}{*}{$\mathrm{LQ} \times \mathrm{LI}$} & & NS & NS & NS & NS & $* *$ \\
\hline & & & & Must & & \\
\hline \multirow[t]{3}{*}{105} & $\mathrm{R}_{74}: \mathrm{G}_{18}: \mathrm{B}_{8}$ & $86.03 \mathrm{~b}$ & 9.08 & 132.32 & 48.11 & $42.48 \mathrm{ab}$ \\
\hline & $\mathrm{R}_{87}: \mathrm{B}_{13}$ & $70.72 \mathrm{~d}$ & 7.67 & 106.95 & 47.10 & $42.24 \mathrm{ab}$ \\
\hline & $\mathrm{R}_{84}: \mathrm{FR}_{7}: \mathrm{B}_{9}$ & $95.37 \mathrm{a}$ & 8.24 & 189.88 & 47.15 & $47.10 \mathrm{a}$ \\
\hline \multirow[t]{3}{*}{210} & $\mathrm{R}_{74}: \mathrm{G}_{18}: \mathrm{B}_{8}$ & $74.51 \mathrm{~cd}$ & 6.84 & 84.67 & 42.67 & $33.26 \mathrm{bc}$ \\
\hline & $\mathrm{R}_{87}: \mathrm{B}_{13}$ & $76.84 \mathrm{c}$ & 6.72 & 81.40 & 39.92 & $35.95 \mathrm{bc}$ \\
\hline & $\mathrm{R}_{84}: \mathrm{FR}_{7}: \mathrm{B}_{9}$ & $58.49 \mathrm{e}$ & 8.31 & 100.22 & 39.13 & $38.88 \mathrm{ab}$ \\
\hline \multirow[t]{3}{*}{315} & $\mathrm{R}_{74}: \mathrm{G}_{18}: \mathrm{B}_{8}$ & $57.08 \mathrm{e}$ & 5.98 & 91.99 & 38.16 & $41.91 \mathrm{ab}$ \\
\hline & $\mathrm{R}_{87}: \mathrm{B}_{13}$ & $48.23 \mathrm{f}$ & 5.58 & 98.44 & 38.53 & $27.40 \mathrm{c}$ \\
\hline & $\mathrm{R}_{84}: \mathrm{FR}_{7}: \mathrm{B}_{9}$ & $51.83 \mathrm{f}$ & 5.58 & 84.42 & 35.84 & $33.60 \mathrm{bc}$ \\
\hline LQ & & $* * *$ & NS & NS & NS & * \\
\hline LI & & $* * *$ & $* * *$ & * & $* * *$ & $* * *$ \\
\hline $\mathrm{LQ} \times \mathrm{LI}$ & & $* * *$ & NS & NS & NS & $* *$ \\
\hline
\end{tabular}

${ }^{\mathrm{z}}$ Mean values are based on a representative sample from each treatment across two experimental replications. ${ }^{y}$ Means sharing a letter are not statistically different by Tukey's honestly significant difference test at $P \leq$ 0.05 . Means with no lettering were found to have no significant interaction between LI and LQ. Ns, ${ }^{*}, * * * *$ Nonsignificant or significant at $P \leq 0.05,0.01$, or 0.001 , respectively.

nutrient dilution was previously investigated in chrysanthemum (Chrysanthemum xmorifolium Ramat. 'Fiesta') by Kuehny et al. (1991). Specifically, they found that nutrient concentration of chrysanthemum was higher under elevated $\mathrm{CO}_{2}$ and increased irradiance. However, most of the differences observed between treatments were removed when data were expressed on a starch-free DW basis. Thus, they proposed that the increased $\mathrm{CO}_{2}$ and irradiance led to a dilution of nutrient content due to the associated increase in growth (Kuehny et al., 1991). This finding may help to explain the higher nutrient levels we observed with all three species of Brassica microgreens under lower LIs. However, given that microgreens are typically sold on a FW basis, production under lower LIs may result in crops that are more nutrient dense.

At a LI of $315 \mu \mathrm{mol} \cdot \mathrm{m}^{-2} \cdot \mathrm{s}^{-1}$, mizuna grown with a light ratio of $\mathrm{R}_{74}: \mathrm{G}_{18}: \mathrm{B}_{8}$ accumulated
$22 \%, 20 \%$, and $14 \%$ more $\mathrm{N}, \mathrm{K}$, and $\mathrm{Ca}$, respectively, compared with those grown under $\mathrm{R}_{84}: \mathrm{FR}_{7}: \mathrm{B}_{9}$ (Table 3). Similarly, mustard accumulated $26 \%, 13 \%$, and $10 \%$ more $\mathrm{K}, \mathrm{Ca}$, and $\mathrm{B}$, respectively, when grown under a light ratio of $\mathrm{R}_{74}: \mathrm{G}_{18}: \mathrm{B}_{8}$ compared with those grown under $\mathrm{R}_{84}: \mathrm{FR}_{7}: \mathrm{B}_{9}$ when provided a $\mathrm{LI}$ of $315 \mu \mathrm{mol} \cdot \mathrm{m}^{-2} \cdot \mathrm{s}^{-1}$ (Tables 3 and 4 ). Kohlrabi accumulated $15 \%$ and $17 \%$ more $\mathrm{B}$ and $\mathrm{Fe}$, respectively, when grown under a light ratio of $\mathrm{R}_{74}: \mathrm{G}_{18}: \mathrm{B}_{8}$ compared with those grown under $\mathrm{R}_{84}: \mathrm{FR}_{7}: \mathrm{B}_{9}$ under a LI of $315 \mu \mathrm{mol} \cdot \mathrm{m}^{-2} \cdot \mathrm{s}^{-1}$ (Table 4). Lastly, while differences were not always significant, there was a trend for microgreens grown with a LI of $315 \mu \mathrm{mol} \cdot \mathrm{m}^{-2} \cdot \mathrm{s}^{-1}$ under the light ratio of $\mathrm{R}_{74}: \mathrm{G}_{18}: \mathrm{B}_{8}$ to consistently display higher nutrient content compared with those under $R_{87}: B_{13}$ for the same nutrients and species. As previously stated, Kopsell and Sams (2013) found that broccoli microgreens grown under a light ratio of $\mathrm{R}_{0}: \mathrm{B}_{100}$ produced significantly higher concentrations of all essential elements compared with those under $\mathrm{R}_{12}: \mathrm{B}_{88}$ at a $P P F$ of 41 and $350 \mu \mathrm{mol} \cdot \mathrm{m}^{-2} \cdot \mathrm{s}^{-1}$, respectively. Further research by Kopsell et al. (2014) validated the hypothesis that nutrient-dense microgreens could be produced under high percentages of blue light. Specifically, blue wavelengths of light have been shown as a dominant means of regulating the processes involved in nutrient content, such as proton pumping, ion channel activities, and membrane permeability (Kopsell et al., 2014). However, results from the present study display that, under higher LIs, the content of specific macro- and micronutrients may benefit from the presence of green wavelengths as well. However, it is uncertain whether the increased nutrient content under the light ratio of $\mathrm{R}_{74}: \mathrm{G}_{18}: \mathrm{B}_{8}$ was due to the presence of green wavelengths or the absence of far-red wavelengths. Thus, future research should look further into the implications of increasing green light and its potential impact on nutrient content for these microgreens species.

Results from this study on growth, morphology, and nutrient content can be used by growers to select the LI and LQ required to achieve preferred growth characteristics of Brassica microgreens. Now, recommendations on light recipes for the production of Brassica microgreens will depend strongly on the market targeted for consumption and the morphological attributes desired by the grower. The data presented should provide adequate information to allow those interested in using these technologies to make informed decisions regarding the production of microgreens based on market needs.

\section{Literature Cited}

Folta, K.M. 2004. Green light stimulates early stem elongation, antagonizing light-mediated growth inhibition. Plant Physiol. 135:1407-1416.

Frantz, J.M. 2013. Uptake efficiency of phosphorus in different light environments by zinnia (Zinnia elegans) and vinca (Catharanthus roseus). HortScience 48:594-600.

Goto, E. 2012. Plant production in a closed plant factory with artificial lighting. Acta Hort. 956: $37-49$.

Heins, R.D., B. Liu, and E.S. Runkle. 2000. Regulation of crop growth and development based on environmental factors. Acta Hort. 511:13-22.

Hoagland, D.R. and D.I. Arnon. 1950. The waterculture method for growing plants without soil. California Agr. Expt. Sta. Circ. 347:32.

Jarvis, P.G. 1964. The adaptability to light intensity of seedlings of Quercus petraea (Matt.). Liebl. J. Ecology 52:545-571.

Kopsell, D.A. and C.E. Sams. 2013. Increase in shoot tissue pigments, glucosinolates, and mineral elements in sprouting broccoli after exposure to short-duration blue light from light-emitting diodes. J. Amer. Soc. Hort. Sci. 138:31-37.

Kopsell, D.A., C.E. Sams, T.C. Barickman, and R.C. Morrow. 2014. Sprouting broccoli accumulate higher concentrations of nutritionally important metabolites under narrow-band lightemitting diode lighting. J. Amer. Soc. Hort. Sci. 139:469-477

Kuehny, J.S., M.M. Peet, P.V. Nelson, and D.H. Willits. 1991. Nutrient dilution by starch in $\mathrm{CO}_{2}$-enriched chrysanthemum. J. Expt. Bot. 42:711-716. 
Li, Q. and C. Kubota. 2009. Effects of supplemental light quality on growth and phytochemicals of baby leaf lettuce. Environ. Exp. Bot. 67:59-64.

Pettai, H., V. Oja, A. Freiberg, and A. Lasik. 2005. Photosynthetic activity of far-red light in green plants. Biochim. Biophys. Acta 1708:311-321.

Potter, T.I., S.B. Rood, and K.P. Zanewich. 1999. Light intensity, gibberellin content and the resolution of shoot growth in Brassica. Planta 207:505-511.

Resh, H.M. 2013. Water culture: Microgreens, p. 135-142. 7th ed. In: H.M. Resh (ed.). Hydroponic food production. CRC Press, Boca Raton, FL.

Samuoliené, G., A. Brazaityte, J. Jankauskiene, A. Virsile, R. Sirtautas, A. Novickovas, S. Sakalauskiene, J. Sakalauskaite, and
P. Duchovskis. 2013. LED irradiance level affects growth and nutritional quality of Brassica microgreen. Cent. Eur. J. Biol. 8: 1241-1249.

Thapper, A., F. Mamedov, F. Mokvist, L. Hammarstrom, and S. Styring. 2009. Defining the far-red limit of photosystem II in spinach. Plant Cell 21:2391-2401.

Treadwell, D.D., R. Hochmuth, L. Landrum, and W. Laughlin. 2010. Microgreens: A new specialty crop. Univ. Florida IFAS Ext. Bul. HS1 164.

United States Department of Agriculture. 2016. Fruit and vegetable market news. 19 Jan. 2016. $<$ https://www.marketnews.usda.gov/>.
Wollaeger, H.M. and E.S. Runkle. 2014. Growth of impatiens, petunia, salvia, and tomato seedlings under blue, green, and red light-emitting diodes. HortScience 49:734-740.

Xiao, Z., G.E. Lester, Y. Luo, and Q. Wang. 2012. Assessment of vitamin and carotenoid concentrations of emerging food products: Edible microgreens. J. Agr. Food Chem. 60:7644-7651.

Yeh, N. and J. Chung. 2009. High-brightness LEDs-Energy efficient lighting sources and their potential in indoor plant cultivation. Renew. Sustain. Energy Rev. 13:21752180 .

Zhang, T. and K. Folta. 2012. Green light signaling and adaptive response. Plant Signal. Behav. 7:1-4. 